\title{
Hyperandrogenism secondary to topical testosterone exposure
}

\author{
A Carroll, S Moloney, NP Murphy \\ From 7th APPES Biennial Scientific Meeting \\ Nusa Dua, Bali. 14-17 November 2012
}

Topical testosterone gels are now a widely used method of testosterone replacement therapy and have been shown to be convenient and effective [1]. The unintentional transfer of testosterone gel to children or partners by skin contact is a rare but significant adverse effect [2].

A 3-year-old well girl was referred for assessment of precocious puberty. Pubic hair had been first noted by her mother 9 months earlier. Examination revealed a tall girl $\left(>99.9^{\text {th }}\right.$ centile) with no breast development but Tanner stage III pubic hair and cliteromegaly. Testosterone levels were elevated at $2.5 \mathrm{nmol} / \mathrm{l}$, as was her Androstenedione level at $1.1 \mathrm{nmol} / 1$. $17 \mathrm{OH} \mathrm{P}$ was normal and tumour markers were negative. Urine steroid profile was quantitatively normal but there was a modest increase in androgen metabolites. Bone age was advanced by 16 months. Ultrasound and MRI imaging of her ovaries and adrenals did not reveal a source of androgen production.

Upon further direct questioning, her father revealed he was using topical testosterone replacement therapy. Her father was advised of measures to reduce secondary exposure. Her repeat testosterone level fell to $<0.7 \mathrm{nmol} / \mathrm{l}$ upon retesting 4 months later and the cliteromegaly resolved. At follow up a further six months later, testosterone level had risen to $2.5 \mathrm{nmol} / \mathrm{l}$. Switching to the use of IM preparations was encouraged. Follow-up testing after these measures were adopted revealed normal undetectable testosterone levels $(<0.7 \mathrm{nmol} / \mathrm{l})$.

Once daily application of testosterone gels to the skin results in relatively stable and physiological testosterone levels in most users[3]. It is often favoured above the other methods of delivery of testosterone as it is painless, discrete and convenient to use. Even small quantities of transferred testosterone may result in clinical signs of hyperandrogenism.

Department of Endocrinology, Children's University Hospital, Temple Street, Dublin 1, Ireland
When reviewing children with evidence of virilization, we must remember to question parents about the potential for exogenous androgen exposure.

Published: 3 October 2013

\section{References}

1. McNicholas TA, et al: A novel testosterone gel formulation normalizes androgen levels in hypogonadal men, with improvements in body composition and sexual function. BJU Int 2003, 91(1):69-74.

2. Kunz GJ, et al: Virilization of young children after topical androgen use by their parents. Pediatrics 2004, 114(1):282-4.

3. Steidle $C$, et al: AA2500 testosterone gel normalizes androgen levels in aging males with improvements in body composition and sexual function. J Clin Endocrinol Metab 2003, 88(6):2673-81.

doi:10.1186/1687-9856-2013-S1-P66

Cite this article as: Carroll et al:: Hyperandrogenism secondary to topical testosterone exposure. International Journal of Pediatric Endocrinology 2013 2013(Suppl 1):P66.
Submit your next manuscript to BioMed Central and take full advantage of:

- Convenient online submission

- Thorough peer review

- No space constraints or color figure charges

- Immediate publication on acceptance

- Inclusion in PubMed, CAS, Scopus and Google Scholar

- Research which is freely available for redistribution
() Biomed Central
C Biomed Central

C 2013 Carroll et al; licensee BioMed Central Ltd. This is an Open Access article distributed under the terms of the Creative Commons Attribution License (http://creativecommons.org/licenses/by/2.0), which permits unrestricted use, distribution, and reproduction in any medium, provided the original work is properly cited. 